\title{
Copyright Issues in Archives
}

\begin{abstract}
The purpose of this paper is to examine the policy process, the stakeholders, the individual policies, the public debate, and the impact that copyright, specifically fair dealing, has on access to and interaction with audiovisual digital archival content in academic archives in Canada. The paper takes a preliminary look at the Copyright Act of Canada, RSC 1985, c C-43, as well as differences between fair use and fair dealing. It then outlines two possible applications of the Copyright Act in archives by looking at digital watermarks and take-down policies.
\end{abstract}

\footnotetext{
About the Author: Andrea Kampen is a recent graduate of Dalhousie University's Master of Library and Information Studies program (2015). She is drawn to the study and practice of how we interact with different mediums of information, from print and text to digital and images. She brings to the profession of Libraries and Archives a keen interest in the treasure hunt that is helping people find the information they are looking for.
} 


\section{Introduction}

Certain preconceptions of archives conjure up images of dusty shelves that are either so organized they should not be touched, or a disastrous mess of piles upon piles of manuscripts with illegible writing. In this image, a socially inept and overly possessive archivist putters about, suggesting that interacting with the content of the records is beyond the capability of a layperson. As with most preconceptions, the possibility that this conclusion stems from some actual experience may be true, but many archivists would balk at the description. This commonly held image of archives does, however, touch on aspects of the many important issues that archives and archivists face everyday: location, types of records, organization of records, and access to records (see Figure 1).

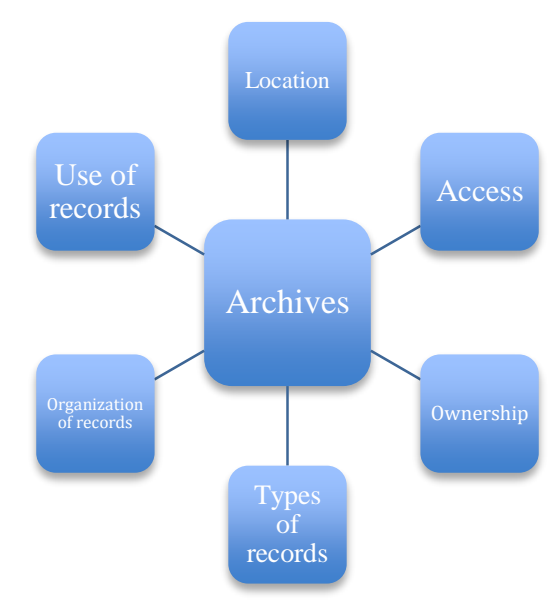

Figure 1. Factors influencing archives

\section{Factors Influencing Archives}

\section{Location}

Archives are repositories for cultural history and can be housed in various types of rooms, buildings, and vaults (Bellini et al., 2003). Indeed, one of the major challenges facing archives is space. For centuries, the space required to house archival collections has been physical, but with the creation of digital objects, terabytes of data are now located on servers. These data are accessed through mobile or desktop interfaces that present different types of demands on physical space and energy.

\section{Types of Records and Organization}

The content in archives now ranges from textual documents, such as manuscripts and books, to audio and visual materials, which includes reel to reel, DVDs, and the 
archivist coaster (floppy disks). There are varying storage needs for these different materials and disparate forms of access.

\section{Access}

Materials frequently find their way into the archive through donation, which presents issues surrounding ownership (Bellini, et al., 2003, p.774) (see Figure 2). What does it mean to "own" materials of cultural value? Ownership and access issues are inextricably linked; if ownership is an issue, who has the right to decide who has access to the material, and how are those decisions reached? A further question also arises around what can be done with the material once it has been accessed.

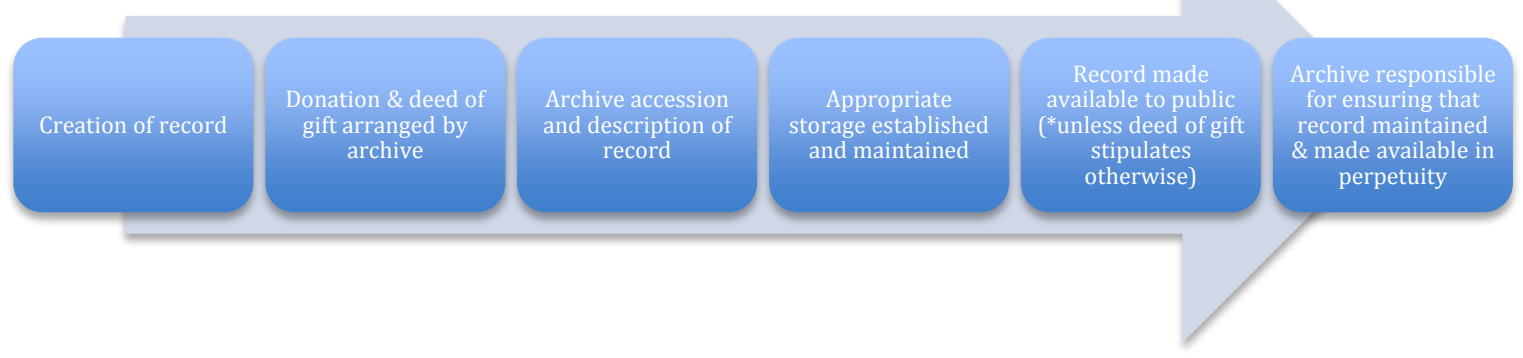

Figure 2. Record processing in an archive

The following paper sets out to examine the policy process, the stakeholders, the individual policies, the public debate, and the impact that copyright, and specifically fair dealing, has on access to and interaction with audiovisual digital archival content in an academic archive in Canada (see Figure 3). By exploring existing literature, evaluating the Copyright Act of Canada, and examining take-down policies, this paper seeks to provide context to get a closer look at the implications of applying the Copyright Act. 


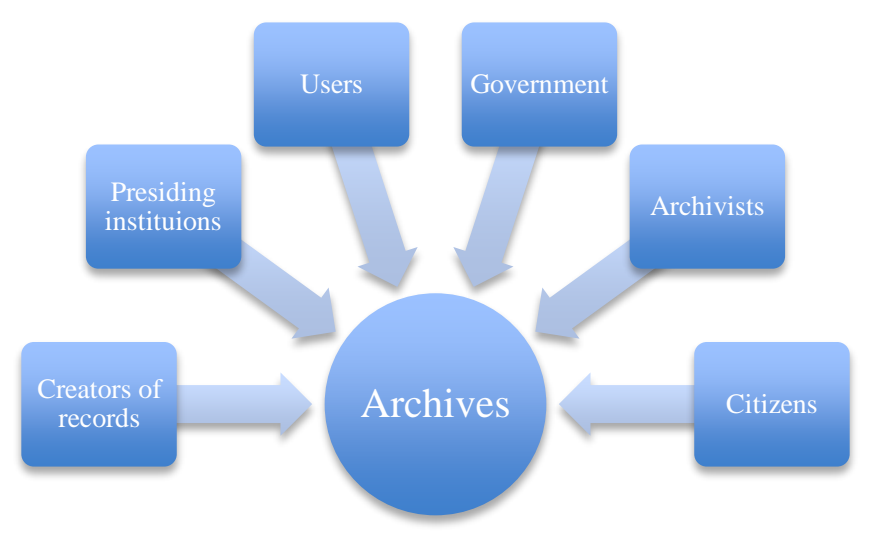

Figure 3. Stakeholders in archival policies

\section{Policy Process for Complying with the Copyright Act of Canada, RSC 1985, c C-43}

The policy process involved in the digital content of archives brings together the aforementioned factors and the stakeholders involved. The fair dealing exception of copyright law is of particular interest with regards to policy process. The reforms that have been made to the Copyright Act of Canada, RSC 1985, c C-43 show how policies can evolve to more accurately reflect the needs of its citizens and the use of the copyright law. Policymakers understand that copyright law is indeed still "a work in progress", and are thus willing to continue to make appropriate amendments to reflect the new ways of viewing the concept of intellectual property (Canadian Heritage, 2013, para. 4). The amendments of 2012 will be re-evaluated by Parliament in 2017.

\section{Copyright Law}

Before looking at fair dealing and other exemptions, we must consider that copyright rules in Canadian Copyright law exist to protect artistic works from unauthorized or inappropriate sale or use. This protection is achieved by granting legal rights to the creators of the intellectual work for exclusive use of that work for a particular period of time (Rao, 2003). Canadian copyright law has undergone several reforms since its creation in 1924 (Canadian Heritage, 2013), which have been guided by the application of new technologies (e.g. satellite, broadband, Internet, piracy, ability to create content). Most recently, it underwent changes seen in Bill C-1 1 of the Copyright Modernization Act (CMA), which was motivated by the need to more appropriately deal with digital content (Stastna, 2011). The CMA was passed in 2012 and expanded the fair dealing categories from five (research, private study, news reporting, criticism, and review) to eight, adding education, parody, and satire. It also provided additional 
educational exemptions, including the screening of films and the use of material from publically available Internet sites. In 2015, the Notice and Notice regime, the final part of the CMA, came into effect, requiring ISPs to pass on infringement notices to users. The Supreme Court issued five copyright cases in 2012, dubbed the "copyright pentalogy," which reinforced support for fair dealing (Geist, 2013, p. iii). These changes occurred after there had been an extensive public review of the Copyright Act in 2009 (Stastna, 2011; Canadian Heritage, 2013).

\section{Fair Dealing Exception}

Drilling down specifically to the fair dealing exception, an integral part of the reform, we can learn about the application of the law appropriate to an archives setting. In order to establish if use is appropriate under fair dealing it must pass two tests. First, if use falls under "the purpose of research, private study, education, parody or satire does not infringe copyright" category, users are permitted to engage with artistic works protected under the Copyright Act (Copyright Act 29). The last three categories (education, parody and satire) were added during the Copyright Modernization Act in 2012. The second test is qualitative in nature and is done in order to establish if the use is indeed "fair" (CMEC Copyright Consortium, 2011). In the 2004 case CCH Canada Ltd. v Law Society of Upper Canada, the Supreme Court of Canada established the appropriateness of fair dealing by identifying the six factors of purpose, character, amount, nature, alternative options, and effect (Meurer, 2011), which are weighed to evaluate a particular use or dealing. It is while enforcing these policies, however, that we are encouraged to consider the strength of the policies themselves.

\section{Fair Dealings vs. Fair Use}

Though this paper is examining a specifically Canadian context, an important distinction needs to be made between fair dealing in the Commonwealth countries and fair use employed in the United States, Israel, and other countries (Geist, 201 1). Fair use allows greater flexibility in its execution because it does not exhaustively list the appropriate applications of "criticism, comment, news reporting, teaching, scholarship and research as illustrative Fair Use purposes, leaving open the possibility of the identification of additional purposes through case law" (Geist, 2011, p. 161). It includes "such as" instances and lists categories, which prevents the lists from being overly extensive. Fair dealing on the other hand has become more lax since 201 1, but still struggles with the balance between the rights of the creator and the user (Geist, 2011). These policies are written by the government, but interpretation and implementation is left to the courts (D'Agostino, 2013), who argue that fair dealing must be interpreted in a "large and liberal" manner (Geist, 2013, p. 158). 
There are also some who argue the distinction between fair use and fair dealing is disappearing, or no longer as concerning. Di Valentino (2013) suggests that the fair dealing law has broadened use to educational institutions in a way that reflects users needs but that the institutions are not fully taking advantage of these amendments out of concern or lack of understanding of the consequences of the CMA. Likewise, Katz (2013) states that Canada should "upgrade from Fair Dealing 1.9 to Fair Use 2.0," thanks to the open-ended provisions of the CMA (p.94).

\section{Stakeholders and Policies in the Application of Copyright Law}

\section{Rights of Users and Creators}

The balance between the rights of the creator and the user is always a factor, regardless of fair use or fair dealing. Focusing, once again, on the digital content in an academically affiliated archive, fair dealing is particularly relevant when considering how it provides exemptions for education and research purposes. The archive, library, or museum must make decisions appropriate to their own interests as a broker or provider of the record, as well as considering the creator and the user. The three main issues for users and content providers alike are service, technical capabilities, and financial support. The content of the record must hold value for the user and the provider, and the latter must be able to make the content available in a way that is most convenient to the user. However, this is impacted by the technical capabilities of the provider. The provider must also be able to provide the services via the technical ability and support that they themselves have. Both service and technical capabilities are further impacted by financial backing (Ongena et al., 2012). Archives, for example, have relied on solidifying large project specific donations to support innovative undertakings. All of these factors are influenced by the organization's compliance with Canadian copyright law.

\section{Copyright Law in University Libraries}

Simon Fraser University (SFU) Library, a leader in copyright policy, is an excellent example of institutional guidance through policies for employees and students to help them identify the appropriate application of fair dealing. After all, it is the application of compliance to the fair dealing exemption for which the archives is responsible. SFU provides valuable definitions to guide the users' decisions and protects the library and archive from breaching copyright law. The policy that SFU created is meant to help balance the rights of user and creator through right of reproduction, right of distribution, right of public performance, right of broadcasting, right of adaptation, right of sale, rental and hire, and right of translation (Rao, 2003). The SFU policy situates 
the issue of copyright in the context of a digital archive, indicating how archives can rely on fair dealing to encourage access while complying with the law (Dancy, 2014). The purpose of creating these policies is to bring together the archive, library, and museum communities to balance the interests of accessing material and copyright owner rights. This is particularly relevant in the digital age, which allows for remote access to digital content for downloading, copying, and sharing copied content, as well as an increased demand for such content (Handman, 2010).

\section{Digital Audiovisual Content}

Let us consider the factors at work for digital audiovisual content available through the archives. Of the six factors identified by the Supreme Court that were mentioned previously, "amount" is particularly relevant to digital content, "given the ease and magnitude with which digital works are disseminated over the Internet" (Society of Composers, Authors and Music Publishers of Canada v. Bell Canada, 2012 SCC 36, Section 43). Focusing on the number of previews streamed would lead to disproportionate and unfair results when compared to non-digital works, and would go against the "goal of technological neutrality" (D'Agostino, 2013, p. 192). Archives may see an increase in engagement because previews of works for free would "encourage creation and dissemination of works" (D'Agostino, 2013, p. 193).

D'Agostino (2013) suggests that Internet service providers have taken on the role of intermediaries as well as navigators of the copyright law - a role played in the past by librarians and archivists. An example of this is Society of Composers, Authors and Music Publishers of Canada v. Bell Canada, 2012 SCC 36, which found that 30 second preview clips of musical tracks on sites that sell Mp3s count as "Fair Dealing for the purpose of research," as outlined in section 29 of Copyright Act of Canada.

\section{Digital Format}

According to Craig (2010), digital format can both advance copyright law and simultaneously undermine the current copyright system. Digital technologies have increased the ease with which the general public produce, interact with, and share content. This sharing is what gives content its value. Rather than seeing this emergence as a positive thing, Craig suggests that policymakers understand digital technology as a threat. Just as librarians must ensure that copyright is not being infringed upon in their libraries, Internet providers also have to consider their responsibility in upholding copyright. Peer-to-peer networking is increasingly viewed by the public as a powerful tool, and could have an increasingly positive impact on archives and libraries. However, the ability to connect people looking for and sharing files, respectively, has manifested in technology used mostly for piracy and illegal file sharing (Office of 
Information and Technology, n.d.). According to Handman (2010), official peer-topeer networking has the potential to empower users, creators, and distributors, including archives, to provide streaming and video on-demand services.

The copyright issues surrounding peer-to-peer networks are interesting when considering audiovisual materials because the richness and value of the record is in its relation to other records (Meurer, 2011). The particular needs of audiovisual records in an academically-affiliated archive are well suited to digital versions of material. Digital versions of audiovisual material can continue to be converted to different formats, thus protecting the originals while also making the content available to a broader audience (Ongena, et al., 2012). Ongena et al. (2012) identified another issue surrounding the volume of audiovisual content in archives as a long-tail problem. A long tail problem means that only a small portion at the beginning and at the end of the content are considered relevant, while everything in between is of lesser interest. By digitizing the content, it will be easier for archives to distribute content to their users, and will allow for improved compliance with copyright laws, including making accessible only those parts of a work that are necessary or allowable in fair dealing analysis (Ongena et al., 2012).

The importance of audiovisual records is increasingly recognized as vital to heritage, and funding to digitize archival records is crucial to improving access. This access is empowered by the technologies that are pushing copyright forward. Digitization of archival content also empowers archives to improve service, save content from deterioration, and attract new users (Bellini et al., 2003). All stakeholders benefit, which improves archives and national heritage in the process. Section 30.1 of the Copyright Act details the specifics of digitization for preservation purposes.

\section{Public Debate, the Role of Internet Providers, and Digital Locks}

Public debate surrounding fair dealing in Canada has been a divisive issue. Some feel that the reform to the law has gone too far, while others think it has not gone far enough. Digital content issues include downloading (Becker, 2004), conflicts between commercial parties and the institutions that distribute the content (Handman, 2010), difficult translation between formats (e.g. mobile, to television, or .docx to PDF), rights to make backups, as well as the power to appropriately manage content (Jackson \& Shah, 2005). The responsibility of Internet providers to pass on claims of users' copyright infringement is viewed by Geist as a positive thing since violators of copyright who receive a notice from their Internet provider rarely offend again (Stastna, 2011). Additionally, Internet providers and search engines have also been exempt from 
responsibility for their users' actions. The inclusion of education, parody, or satire as appropriate uses under the fair dealing exception has also been widely embraced.

The reformed Copyright Act also has received criticism for its treatment of digital locks (Stastna, 2011). Digital locks are technologies such as "passwords, encryption software and access codes" that prohibit access to copyrighted material (Government of Canada, 2011). Bill C-11, the Copyright Modernization Act, outlines situations where breaking a digital lock is appropriate, such as law enforcement, national security activities, reverse engineering for software compatibility, security testing of systems, and encryption research. However, obvious though it may sound, access is what connects users to the archive, and digitally locking away content is an impediment on that access. There have been several innovations developed for archives to protect themselves and their users from copyright infringement: digital locks and takedown policies. The use of digital materials while complying with copyright requires support for secure distribution and functionalities that allow for the tracking of "exploited functionalities" (Bellini, et al., 2003 p.776).

Craig (2010) defines digital locks as "technical protection measures" (p. 503), which can be taken to protect digital content from inappropriate use in violation of copyright law. In the case of digital locks, content creators or institutions that are responsible for records can place digital restrictions on access. The danger, though, is that locks are placed on records that users should have access to. Craig argues that there needs to be a better balance between the rights in the copyright law. Critics of the reformed Copyright Act believe the anti-circumvention aspects of the copyright law to be an issue that upsets the copyright balance (Craig, 2010; Geist, 2011; Stastna, 2011). Geist (2011) suggests that access should not be considered a violation of copyright law. There are several completely appropriate uses of digital content (i.e. a student downloading an article, a journalist using a clip from a video) that would be hindered because it would require circumventing a digital lock. Craig (2010) sees this as a way of undermining the reforms made regarding fair dealing.

Another example of a type of digital lock is a method that has been used with physical counterparts, namely watermarks. Watermarks protect digital content by embedding a signature within the digital document in a way that is not necessarily visible to the user (Briassouli \& Strintzis, 2004). It is a real problem that breaking digital locks, even for preservation purposes, is considered 'law-breaking', as this makes preserving materials like DVDs virtually impossible in archives. 


\section{Takedown Policies}

Takedown policies are an important way for an archive to deal with the conundrum of having to hold back content because receiving express permission is unreasonable. For instance, if a film production company donates its records to an archive, it could be argued that the archive should not make the audio visual content available if it is unable to obtain permission from each individual artist. The paradox of orphan works is of specific interest in this situation. Orphan works are materials for which the "owner of a copyrighted work cannot be identified and located by someone who wishes to make use of the work in a manner that requires permission of the copyright owner" (Peters, 2006, p. 1). This is a complicated issue, as archives can spend an inordinate amount of time attempting to clear copyright on less valuable material if its obscure creators cannot easily be found. An additional challenge facing orphan works is the fact that the Canadian Copyright Board only deals with published material (Canadian Copyright Board, 2001).

In cases where records have been donated and taken ownership by the archive, the following question arises: Does the archive have the right to do whatever they want with the content, regardless of the relationship with the donor? Maintaining a positive relationship with the records creator is what allows archives to continue to receive records. Takedown policies allow archives to provide creators with an opportunity to reclaim copyrighted property, but also allows archives to display its content. While researching this paper, the takedown policies at the British Library, GitHub, The National Archives, Popup Archives, and William and Mary Swem Library were evaluated. This approach showed that takedown policies often share several key components: acknowledgement that the archives sometimes get it wrong, how to contact the archive if an issue is identified, and how and who deals with takedown requests. Importantly, the takedown policies examined also indicate that even if a request is made to take down a record, this does not mean it will be removed. 


\begin{tabular}{|c|c|c|c|c|}
\hline Institution & Acknowledgement & Contact & Process & Possible Outcome \\
\hline $\begin{array}{l}\text { British Library } \\
\text { Fair Dealings }\end{array}$ & $\begin{array}{l}\text { - Acts in good faith } \\
\text { - Recognizes that, } \\
\text { from time to time, } \\
\text { materials are } \\
\text { posted in violation } \\
\text { of copyright, or } \\
\text { may contain } \\
\text { sensitive data }\end{array}$ & $\begin{array}{l}\text { - Notice and Takedown } \\
\text { Licensing department } \\
\text { - Complainants should: } \\
\text { > Include full details of } \\
\text { the material; } \\
\text { > Include exact and } \\
\text { full URL of the } \\
\text { offending material; } \\
\text { > Provide proof of } \\
\text { rights holder; and } \\
\text { > State reason for } \\
\text { request }\end{array}$ & $\begin{array}{l}\text { - The library will } \\
\text { acknowledge } \\
\text { receipt of } \\
\text { complaint (by } \\
\text { email or letter), } \\
\text { provide initial } \\
\text { assessment of the } \\
\text { validity and } \\
\text { plausibility of the } \\
\text { complaint } \\
\text { - Material will be } \\
\text { temporarily } \\
\text { removed if the } \\
\text { complaint is valid } \\
\text { - The library will } \\
\text { contact the } \\
\text { contributor who } \\
\text { deposited the } \\
\text { material, if relevant } \\
\text { - Contributor will be } \\
\text { notified that the } \\
\text { material is subject } \\
\text { to a complaint and } \\
\text { under what } \\
\text { grounds, and will } \\
\text { be encouraged to } \\
\text { deal with the } \\
\text { complaints } \\
\text { concerned }\end{array}$ & $\begin{array}{l}\text { - The record may } \\
\text { be replaced on } \\
\text { the British Library } \\
\text { website } \\
\text { unchanged } \\
\text { - The record may } \\
\text { be replaced on } \\
\text { the website with } \\
\text { changes. } \\
\text { - The record may } \\
\text { be permanently } \\
\text { removed from the } \\
\text { website }\end{array}$ \\
\hline $\begin{array}{l}\text { GitHub } \\
\text { Fair Use }\end{array}$ & $\begin{array}{l}\text { - GitHub acts in } \\
\text { compliance with } \\
\text { Digital Millennium } \\
\text { Copyright Act } \\
\text { - Copyright owner } \\
\text { is responsible for } \\
\text { informing GitHub } \\
\text { of complaint } \\
\text { about a user }\end{array}$ & $\begin{array}{l}\text { - Complainant must fill } \\
\text { out a notice and send } \\
\text { to GitHub at } \\
\text { copyright@github.com }\end{array}$ & $\begin{array}{l}\text { - Copyright owner } \\
\text { conducts an initial } \\
\text { investigation to } \\
\text { confirm both (a) } \\
\text { that they own the } \\
\text { copyright to an } \\
\text { original work and } \\
\text { (b) that the }\end{array}$ & $\begin{array}{l}\text { - Copyright owner } \\
\text { may revise or } \\
\text { retract the notice } \\
\text { - GitHub may } \\
\text { disable access to } \\
\text { the content } \\
\text { - User may send a } \\
\text { counter notice }\end{array}$ \\
\hline
\end{tabular}




\begin{tabular}{|c|c|c|c|c|}
\hline & & & $\begin{array}{l}\text { content is } \\
\text { unauthorized } \\
\text { - Copyright owner } \\
\text { sends notice to } \\
\text { GitHub } \\
\text { - GitHub asks user to } \\
\text { make changes } \\
\text { - User notifies GitHub } \\
\text { of changes }\end{array}$ & $\begin{array}{l}\text { - Copyright owner } \\
\text { may file a legal } \\
\text { action }\end{array}$ \\
\hline $\begin{array}{l}\text { The National } \\
\text { Archives } \\
\text { Fair Dealings }\end{array}$ & $\begin{array}{l}\text { - Information } \\
\text { published on } \\
\text { website } \\
\text { considered public } \\
\text { domain, and will } \\
\text { be removed only } \\
\text { in exceptional } \\
\text { circumstances } \\
\text { - Most records are } \\
\text { 'open' and } \\
\text { anyone can view } \\
\text { them or obtain a } \\
\text { copy of them } \\
\text { - It is rare that an } \\
\text { open record is } \\
\text { closed to public } \\
\text { access }\end{array}$ & $\begin{array}{l}\text { - Take Down panel is } \\
\text { responsible for } \\
\text { assessing complaints } \\
\text { - Panel is comprised of } \\
\text { staff members with } \\
\text { expertise in Freedom } \\
\text { of Information } \\
\text { - Panel should be } \\
\text { contacted if record: } \\
\text { Is impacted by } \\
\text { changed } \\
\text { circumstances; } \\
\text { Shares personal } \\
\text { information; } \\
\text { Infringes copyright; } \\
\text { Is defamatory or } \\
\text { obscene; or Was } \\
\text { released in error }\end{array}$ & $\begin{array}{l}\text { - Request from a } \\
\text { member of the } \\
\text { public or } \\
\text { government } \\
\text { department, } \\
\text { referral is made to } \\
\text { the Nation } \\
\text { Archives } \\
\text { - Material is then } \\
\text { temporarily } \\
\text { restricted while } \\
\text { under revision by } \\
\text { the Take Down } \\
\text { panel }\end{array}$ & $\begin{array}{l}\text { - Original formats of } \\
\text { online material } \\
\text { taken down will } \\
\text { be brought to the } \\
\text { attention of the } \\
\text { Reclosure Panel } \\
\text { - The National } \\
\text { Archives publishes } \\
\text { annual figures for } \\
\text { reclosed records } \\
\text { at series level from } \\
2012 \text { onwards } \\
\text { - Members of the } \\
\text { public to are able } \\
\text { to request access } \\
\text { to a closed } \\
\text { record by making } \\
\text { a request under } \\
\text { the Freedom of } \\
\text { Information Act }\end{array}$ \\
\hline $\begin{array}{l}\text { Popup } \\
\text { Archives } \\
\text { Fair Use }\end{array}$ & $\begin{array}{l}\text { - Popup Archives } \\
\text { requires users to } \\
\text { follow rules in } \\
\text { order to } \\
\text { participate } \\
\text { - Popup Archives } \\
\text { respects the } \\
\text { intellectual } \\
\text { property of others } \\
\text { - If materials have } \\
\text { been copied in a } \\
\text { way that } \\
\text { constitutes }\end{array}$ & $\begin{array}{l}\text { - Complainant must } \\
\text { include: } \\
\text { Description of the } \\
\text { copyrighted work } \\
\text { that has been } \\
\text { infringed; Location } \\
\text { of material; } \\
\text { Address, telephone } \\
\text { number, and email } \\
\text { address of } \\
\text { complainant; } \\
\text { Statement of good } \\
\text { faith that the }\end{array}$ & $\begin{array}{l}\text { - Chief Executive } \\
\text { Officer is } \\
\text { responsible for } \\
\text { processing } \\
\text { complaints }\end{array}$ & $\begin{array}{l}\text { - Did not specify } \\
\text { outcomes }\end{array}$ \\
\hline
\end{tabular}




\begin{tabular}{|c|c|c|c|c|}
\hline & $\begin{array}{l}\text { copyright } \\
\text { infringement they } \\
\text { may be removed }\end{array}$ & $\begin{array}{l}\text { disputed use is not } \\
\text { authorized by the } \\
\text { copyright owner, its } \\
\text { agent, or the law; } \\
\text { and a Statement, } \\
\text { made under } \\
\text { penalty of perjury, } \\
\text { that the } \\
\text { information is } \\
\text { accurate and that } \\
\text { complainant is the } \\
\text { copyright owner or } \\
\text { authorized to act } \\
\text { on the copyright } \\
\text { owner's behalf }\end{array}$ & & \\
\hline $\begin{array}{l}\text { Swem } \\
\text { Library } \\
\text { Fair Dealings }\end{array}$ & $\begin{array}{l}\text { - Records are in the } \\
\text { public domain } \\
\text { - Rights are owned } \\
\text { by The College of } \\
\text { William and Mary } \\
\text { and has } \\
\text { permission to } \\
\text { make them } \\
\text { accessible } \\
\text { - The Library makes } \\
\text { records } \\
\text { accessible for } \\
\text { education and } \\
\text { research purposes } \\
\text { as a legal Fair Use } \\
\text { - There are no } \\
\text { known restrictions } \\
\text { on use }\end{array}$ & $\begin{array}{l}\text { - Requests for removal } \\
\text { go to Digital Archives } \\
\text { administrator or Publish } \\
\text { administrator } \\
\text { - Complaint must } \\
\text { include the name and } \\
\text { url of the item or items } \\
\text { to be removed; } \\
\text { - Reason for removal } \\
\text { and } \\
\text { - Explanation of any } \\
\text { claims to rights for the } \\
\text { material. }\end{array}$ & $\begin{array}{l}\text { - Director of Special } \\
\text { Collections will be } \\
\text { notified } \\
\text { - Consultation with } \\
\text { the Special } \\
\text { Collections staff } \\
\text { and other } \\
\text { appropriate } \\
\text { members of the } \\
\text { campus } \\
\text { community } \\
\text { - The request is } \\
\text { reviewed for just } \\
\text { cause } \\
\text { - Item or items in } \\
\text { question will be } \\
\text { removed from } \\
\text { public view until } \\
\text { the request is } \\
\text { resolved }\end{array}$ & $\begin{array}{l}\text { - Item may not } \\
\text { change and is } \\
\text { returned to public } \\
\text { view. } \\
\text { - Item may not be } \\
\text { changed, but } \\
\text { access is } \\
\text { restricted for a } \\
\text { period of time. } \\
\text { - Item may be } \\
\text { permanently } \\
\text { removed } \\
\text { - Another outcome } \\
\text { may occur }\end{array}$ \\
\hline
\end{tabular}

Table 1. Comparison of take-down policies from institutions using Fair Use or Fair Dealing

\section{Access and Compliance with Copyright Law}

An interesting way of combining these aspects of accessibility and compliance with copyright could be in identifying audiovisual content that archives post online, with users having the opportunity to identify important archival content (Meurer, 2011, p. 58). Such projects include Metadatagames, an open data software that allows users 
to describe archival images. It is an inventive way of dealing with the backlog of content that every archive has to contend with in a way that invites engagement (Metadatagames, 2015). Many users may be able to make connections or identify content that a single archivist may not, such as identifying an obscure photograph or the creator of a short film that the archive has made available for streaming. Archives are built on the principle of context, and with more information present that can provide context for a record, the record, and by extension the archive itself, becomes more valuable.

\section{Conclusion}

The most recent reform of the Canadian copyright law included changes to the fair dealing exceptions, which empower archives to share more content without being in violation of copyright. The Supreme Court of Canada has said that fair dealing is a right and must be interpreted liberally, which should give Canadian archives confidence in relying on it. However, working with digital content requires institutions who are making digital records available to be aware of the advances in technology, and to take part in policy creation to ensure a balance between the rights of the creators and the rights of the users.

Staying abreast of changes to copyright law has very real implications and is not only subject to Canadian law. For instance, there is the possibility that there will be changes to Canadian copyright because of the Trans-Pacific Partnership (TPP) agreement. Specifically, the TPP will strengthen digital locks, which, as explored in this paper, is particularly relevant to audiovisual material. This is especially concerning to archivists as it is a point that ought to be discussed with lawmakers before ratification of the treaty, and as part of the re-evaluation of the CMA in 2017. It is the responsibility of those in the information field to decide whether fair dealing and users' rights are more important than maintaining digital locks. An additional implication of the TPP is that it would keep materials out of the public domain for an additional 20 years in Canada, until 70 years after the death of the author. This is especially applicable to audiovisual material, given that there is significant confusion regarding who the creator or author is. Is it the director? Writer? Producer? Having to wait 70 years after the death of almost everyone involved in the project is not only frustrating, it is unreasonable.

As new technologies are created for accessing, creating, and distributing content, so too must new laws be created, or the existing laws amended, to accommodate the rights of both content creators and users. Those responsible for creating policy in 
archives should unite their experience and expertise to both comply with and influence Canadian copyright law. 


\section{References}

Bellini, P., Barthelemy, J., Bruno, I., Nesi, P., \& Spinu, M. (2003). Multimedia music sharing among mediateques: Archives and distribution to their attendees. Applied Artificial Intelligence, 17(8-9), 773-795. DOI: 10.1080/08839510390225159

Briassouli, A., \& Strintzis, M. (2004). Optimal watermark detection under quantization in the transform domain. IEEE Transactions on Circuits and Systems for Video Technology, 14(12), 1308-1319.

Canadian Heritage. (2013). History of copyright in Canada. Retrieved from http://www.pch.gc.ca/eng/1274383301385

CMEC Copyright Consortium. (2011). FAQs on copyright law.Retrieved from http://www.cmec.ca/docs/copyright/FAQ_EN.pdf

Copyright Act. (R.S.C., 1985, c. C-42). Retrieved from the Department of Justice Canada website: http://laws-lois.justice.gc.ca/PDF/C-42.pdf

Copyright Board of Canada. (2001). Unlocatable copyright owners. Retrieved from http://www.cb-cda.gc.ca/unlocatable-introuvables/brochure2-e.html

Craig, C. (2010). Digital locks and the fate of fair dealing in Canada: In pursuit of "prescriptive parallelism". The Journal of World Intellectual Property, 13(4), 503539. doi: $10.1111 /$ j.1747-1796.2009.00394.x

D'Agostino, G. (2013). The arithmetic of fair dealing at the Supreme Court of Canada. Retrieved from http://digitalcommons.osgoode.yorku.ca/cgi/viewcontent.cgi? article=2598 \&context=scholarly_works\&sei-redir=1 \& referer=https\%3A\%2F\%2Fscholargoogleca.ezproxy.library.dal.ca\%2Fscholar\%3Fq\%3D\%2522fair\%2Bdealing\%2522\%2B AND\%2Bdigital\%2BAND\%2Bcanada\%26btnG\%3D\%26hl\%3Den\%26as_sdt\%3D0 \%252C5\%26as_ylo\%3D2011 \#search=\%22fair\%20dealing\%20digital\%20canada $\% 22$

Darcy, R. (2014). Copyright policy framework for SFU archives digital repository. Retrieved from 
https://wiki.its.sfu.ca/departments/archives/images/b/b9/RptCopyrightPolicy Framework.pdf

Di Valentino, L. (2013). Comparison of fair dealing and fair use in education postpentalogy. Available at SSRN: http://ssrn.com/abstract=2320219 or http://dx.doi.org/10.2139/ssrn.2320219

Geist, M. (2011). The copyright pentalogy. Retrieved from http://www.press.uottawa.ca/sites/default/files/9780776620848_5.pdf

Government of Canada. (2011). What the copyright modernization act says about digital locks balanced copyright. Retrieved from http://www.ic.gc.ca/eic/site/crp-prda.nsf/eng/rp01 182.html

GitHub. (2015). DMCA takedown policy. Retrieved from https://help.github.com/articles/dmca-takedown-policy/

Handman, G. (2010). License to look: Evolving models for library video acquisition and access. Library Trends, 58(3), 324-334.

Jackson, M., \& Shah, A. (2005). The impact of DRMs on personal use expectations and fair dealing rights. Research and Practice in Information Technology, 44. Retrieved from http://crpit.com/confpapers/CRPITV44Jackson.pdf

Katz, A. (2013). Fair use 2.0: The rebirth of fair dealing in Canada. In M. Geist (Ed.), The copyright pentalogy: How the supreme court of Canada shook the foundations of Canadian copyright law (Chapter 4). Retrieved from http://bit.ly/lPKBgFB

Metadatagames. (2015). Metadatagames. Retrieved from http://www.metadatagames.org/

Meurer, D. (2011). Towards a dialogic archive: Canadian copyright law, digital archives and fair dealing. Second International Conference on Culture and Computing. DOI 10.1 109/Culture-Comuting.2011.19

Office of Information and Technology. (n.d.). Copyright infringement, peer-to-peer, and file sharing. Retrieved from https://oit.utk.edu/policies/copyright/Pages/default.aspx 
Ongena, G., Huizer, E., \& Wijngaert, L. (2012). Threats and opportunities for new audiovisual cultural heritage archive services: The Dutch case. Telematics and Informatics, 29(2), 156-165.

Peters, M. (2006). Report on orphan works. United States Copyright Office. Retrieved from http://www.copyright.gov/orphan/orphan-report-full.pdf

Popup Archive. (2013). Terms of service and privacy policy. Retrieved from https://www.popuparchive.com/terms_of_use\#dmca

Rao, S. (2003). Copyright: its implications for electronic information. Online Information Review, 27(4), 264-275. DOI 10.1108/14684520310489050

Simon Fraser University Library. (2015). Copyright at SFU: Law and policy. Retrieved from http://www.lib.sfu.ca/copyright/law-policy

Society of Composers, Authors and Music Publishers of Canada v. Bell Canada, 2012 SCC 36, [2012] 2S.C.R. 326. Retrieved from http://scc-csc.lexum.com/scccsc/scc-csc/en/item/9996/index.do

Stastna, K. (2011). Copyright changes: how they'll affect users of digital content. Canadian Broadcast Corporation.com. Retrieved from http://www.cbc.ca/news/canada/copyright-changes-how-they-Il-affectusers-of-digital-content-1.991691

Swem Library. (2013). W\&M digital archive and W\&M publish take-down policy and disclaimer. Retrieved from https://swem.wm.edu/policies/wm-digital-archiveand-wm-publish-take-down-policy-and-disclaimer

The British Library. (n.d.). Notice and takedown policy. Retrieved from http://www.bl.uk/aboutus/terms/notice/

The National Archives. (n.d.). Takedown and reclosure policy. Retrieved from http://www.nationalarchives.gov.uk/legal/takedown-policy.htm 